\title{
PENGARUH PERASAN DAUN SERAI DAPUR (Cymbopogon citratus) TERHADAP KEMATIAN LARVA Aedes aegypti
}

\author{
Ummi Salami Yatuu' ${ }^{1}$, Herlina Jusuf ${ }^{2}$, Nur Ayini S. Lalu ${ }^{3}$ \\ ${ }^{1,2,3}$ Fakultas Olahraga dan Kesehatan, Universitas Negeri Gorontalo \\ E-mail : ummisalamiyatuu22@ gmail.com HerlinaJusuf@yahoo.co.id Nur.ayini@ung.ac.id
}

\begin{abstract}
Abstrak
Demam Berdarah Dengue (DBD) adalah penyakit yang disebabkan oleh infeksi virus dengue yang ditularkan melalui gigitan nyamuk betina Aedes aegypti yang telah terinfeksi oleh virus dengue. Penelitian ini bertujuan untuk mengetahui pengaruh perasan daun serai dapur dalam membunuh larva Aedes aegypti dan untuk menganalisis pada konsetrasi mana paling berpengaruh dari perasan daun serai dapur terhadap kematian larva Aedes aegypti. Penelitian ini merupakan penelitian dengan rancangan True Experimental. Subjek penelitian adalah 540 ekor larva Aedes aegypti instar II yang berisi 15 ekor larva pada setiap konsentrasi dengan masing-masing kelompok konsentrasi yaitu 15\%, $30 \%$ dan 45\%. Dilakukan 3 kali pengulangan yang diamati selama 6 jam, 12 jam, 18 jam dan 24 jam. Data yang didapat kemudian di analisis dengan menggunakan uji Two Way ANOVA. Berdasarkan hasil uji Two Way ANOVA menunjukan nilai signifikan $0,000(\mathrm{p}<0,05)$, sehingga dapat dikatakan bahwa ada perbedaan yang signifikan antara kelompok perlakuan. Rata-rata kematian larva paling tinggi terdapat pada konsentrasi $45 \%$ dengan persentase sebesar $100 \%$. Sedangkan rata-rata kematian larva yang paling sedikit terdapat pada konsentrasi $15 \%$ dengan persentase sebesar 22\%. Kesimpulan dalam penelitian ini, Perasan Daun Serai Dapur (Cymbopogon citratus) memiliki efek terhadap kematian larva Aedes aegypti Di harapkan masyarakat dapat memanfaatkan tanaman serai dapur yang biasanya di gunakan untuk memasak sebagai pengharum makanan juga bisa menggunakannya sebagai larvasida dalam mengurangi vekor nyamuk DBD.
\end{abstract}

Kata kunci : Larvasida, Aedes aegypti, Cymbopogon citratus.

\section{PENDAHULUAN}

Penyakit yang diakibatkan melalui vektor masih menyumbang angka kejadian penyakit infeksi didunia. WHO (World Health Organization) melaporkan bahwa $17 \%$ dari penyakit infeksi disebabkan oleh vektor. Nyamuk sendiri merupakan vektor yang sangat berperan pada berbagai penyakit, diantaranya malaria, demam berdarah dengue (DBD) dan chikungunya. Didunia penyakit malaria setidaknya telah membunuh 627 ribu orang yang meninggal, sedangkan DBD telah menjangkiti 50-100 juta jiwa pertahun dengan kematian mencapai 20 ribu jiwa. Di Asia Tenggara penyebaran penyakit ini terus mengalami peningkatan penyebaran. Pada tahun 2003 tercatat hanya 8 negara pada regio ini yang terinfeksi demam berdarah, namun pada tahun 2004 bertambah menjadi 9 negara dan hal ini akan terus berlanjut (WHO, 2012).

Demam Berdarah Dengue (DBD) adalah penyakit yang disebabkan oleh infeksi virus dengue yang terdiri dari empat tipe, yaitu DEN-1, DEN-2, DEN-3, DEN-4. Infeksi virus dengue ditularkan melalui gigitan nyamuk betina Aedes aegypti dan Aedes albopictus. Penularan virus dengue tersebut hampir ditemukan di seluruh pelosok Indonesia, kecuali di tempat yang ketinggiannya lebih dari 100 meter di atas permukaan laut (Rahayu, 2017). 
Penyakit DBD merupakan salah satu masalah kesehatan masyarakat di Indonesia. Jumlah kasusnya selalu meningkat dan penyebarannya bertambah luas. Di Indonesia angka kejadian DBD terus mengalami peningkatan, pada tahun 1999 tercatat sekitar 7-10 jiwa per 100 ribu penduduk terjangkit DBD, pada tahun 2010 kejadian DBD mencapai 65,62 jiwa per 100 ribu penduduk, sedangkan pada tahun 2014 sampai pertengahan bulan Desember tercatat penderita DBD di 34 provinsi di Indonesia dengan jumlah 71.668 orang, dan 641 diantaranya meninggal dunia. Angka tersebut lebih rendah dibandingkan tahun sebelumnya yakni pada tahun 2013 dengan jumlah penderita sebanyak 112.511 orang dan sekitar 871 orang meninggal sementara itu pada tahun 2015 tercatat jumlah penderita DBD sebanyak 129.650 orang dan sekitar 1.071 orang yag meninggal (Kemenkes RI, 2015).

Pola penyakit DBD di Indonesia sangat berbeda antara satu wilayah dengan wilayah lainnya. Tingginya angka kejadian DBD juga dapat dipengaruhi oleh kepadatan penduduk. Peningkatan jumlah kasus DBD dapat terjadi bila kepadatan penduduk meningkat, semakin banyak manusia maka peluang tergigit oleh nyamuk Aedes aegypti juga akan lebih tinggi (Pongsilurang, Dkk, 2015).

Berdasarkan data kasus DBD yang di dapat dari Dinas Kesehatan Provinsi Gorontalo, kasus DBD di Provinsi Gorontalo dapat dilihat pada tabel berikut :

Tabel 1.1 Kejadian Penyakit DBD di Provinsi Gorontalo Tahun 2016-2018

\begin{tabular}{|c|c|c|c|c|}
\hline $\begin{array}{l}\mathbf{N} \\
\mathbf{0}\end{array}$ & $\begin{array}{c}\text { Tahu } \\
\text { n }\end{array}$ & $\begin{array}{c}\text { Jumla } \\
\text { h } \\
\text { Kasus }\end{array}$ & $\begin{array}{c}\text { Meninggaa } \\
1\end{array}$ & $\begin{array}{c}\mathbf{C F} \\
\mathbf{R} \\
(\%)\end{array}$ \\
\hline 1 & 2016 & 758 & 21 & 2,77 \\
\hline 2 & 2017 & 504 & 11 & 2,18 \\
\hline 3 & 2018 & 906 & 14 & 1,54 \\
\hline
\end{tabular}

Berdasarkan tabel 1.1 kejadian penyakit DBD di Provinsi Gorontalo pada tahun 2016-
2018 dapat dilihat bahwa jumlah kasus yang terbanyak terdapat pada tahun 2018 dengan jumlah kasus sebanyak 906 dengan kematian sebanyak 14 orang, dan jumlah kasus yang paling sedikit terdapat pada tahun 2017 dengan jumlah kasus 504 dengan kematian 11 orang.

Tabel 1.2 Data Kasus Penyakit DBD di Provinsi Gorontalo Tahun 2018

\begin{tabular}{|c|c|c|c|}
\hline No & Tempat & $\begin{array}{c}\text { Jumlah } \\
\text { Kasus }\end{array}$ & Meninggaal \\
\hline 1 & Kota Gorontalo & 94 & 2 \\
\hline 2 & $\begin{array}{c}\text { Kabupaten } \\
\text { Gorontalo }\end{array}$ & 244 & 4 \\
\hline 3 & $\begin{array}{c}\text { Kabupaten } \\
\text { Boalemo }\end{array}$ & 51 & 3 \\
\hline 4 & $\begin{array}{l}\text { Kabupaten } \\
\text { Pohuwato }\end{array}$ & 303 & 2 \\
\hline 5 & $\begin{array}{c}\text { Kabupaten } \\
\text { Bonebolango }\end{array}$ & 111 & 3 \\
\hline 6 & $\begin{array}{c}\text { Kabupaten } \\
\text { Gorontalo } \\
\text { Utara }\end{array}$ & 103 & - \\
\hline & Jumlah & 906 & 14 \\
\hline
\end{tabular}

Sumber : Dinas Kesehatan Provinsi Gorontalo, 2019

Berdasarkan tabel 1.2 kejadian penyakit Demam Berdarah Dengue di Provinsi Gorontalo tahun 2018 paling banyak terdapat di Kabupaten Pohuwato dengan jumlah kasus sebanyak 303 dengan jumlah yang meninggal sebanyak 2 orang sedangkan jumlah kasus DBD yang paling sedikit terdapat di Kabupaten Boalemo dengan jumlah kasus 51 dan yang meninggal sebanyak 3 orang.

Sampai saat ini penyakit DBD merupakan masalah kesehatan masyarakat di Indonesia dan sering menimbulkan suatu kejadian luar biasa (KLB) dengan kematian yang besar. Penyakit ini bukan hanya terjadi di daerah perkotaan saja melainkan sudah terjadi di daerah pedesaan. Berbagai usaha untuk mengatasi DBD sudah dilakukan namun belum optimal, sehingga perlu dilakukan upaya untuk memutuskan rantai penyebaran nyamuk tersebut yaitu dengan cara pengendalian vektor dengan menggunakan insektisida. 
Insektisida memliki beberapa efek samping, yaitu resistensi pada nyamuk dan larva, resiko kontainasi air dan makanan, serta menyebabkan akumulasi residu kimia pada flora, fauna, tanah dan lingkungan. Dalam usaha untuk mengurangi efek samping dari penggunaan insektisida kimia maka perlu dicari alternatif lain yang lebih aman dan ekonomis serta tidak menimbulkan dampak terhadap manusia tetapi bermanfaat untuk pemberantas vektor. Oleh karena itu insektisida nabati merupakan salah satu alternatif yang dapat digunakan dalam pengendalian vektor (Adhli, 2014).

Salah satu alternatif dengan menggunakaan insektisida nabati sebagai larvasida alami yaitu dengan memanfaatkan tanaman serai dapur. Serai atau Cymbopogon citratus adalah tanaman rempah yang keberadaannya sangat melimpah di Indonesia. Tanaman serai banyak dibudidayakan pada ketinggian 200-800 di atas pemukaan laut. Serai memiliki nama familiar yang berbeda-beda di setiap daerahnya seperti sereue mongthi (Aceh), sere (Gayo), sangge-sangge (Batak), serai (Batawi) (Minangkabau), sarae (Lampung), sere (Melayu), sereh (Sunda), sere (Jawa Tengah), sere (Madura), dan di Gorontalo tanaman serai dikenal dengan nama Timbuale serta masih banyak nama lain untuk menyebutkan serah di daerah lain (Sastriawan, 2014).

Ada dua jenis tanaman serai yaitu serai wangi (Cymbopogon nardus L) dan serai dapur (Cymbopogon citratus), kedua tanaman serai ini memiliki perbedaan yaitu serai dapur punya bentuk pangkal batang yang lebih besar, berisi, dan pangkal batangnya berwarna putih, aromanya tidak terlalu tajam, dan rasanya sedikit pahit. Bagian dalamnya yang masih muda digunakan sebagai bumbu untuk masakan atau sambal. Sedangkan batang serai wangi lebih ramping dan pangkal batangnya berwarna merah, aromanya lebih kuat sehingga dipakai untuk pembuatan minyak atau sabun serai.

Meskipun kedua tanaman ini sama-sama mampu menghasilkan minyak atrisi, namun di Indonesia sendiri hanya serai wangi saja yang banyak diolah sebagai penghasil minyak atsiri (Muhlisah, 2012).

Di Gorontalo Serai Dapur (Cymbopogon citratus) dikenal dengan istilah timbuale. Biasanya masyarakat Gorontalo memanfaatkan serai sebagai bumbu dapur untuk pengharum makanan dan penambah rasa pada makanan serta untuk tanaman obat tradisional. Keberadaan tanaman serai di Gorontalo mudah ditemukan dan tumbuh dimana-mana, tanaman serai ini juga banyak dapat digunakan sebagai pengusir nyamuk dan dapat mencegah penyakit DBD karena aromanya tidak disukai oleh nyamuk.

Raditya (2018) meneliti tentang Uji Efektivitas Ekstra Daun Serai (Cymbopogon citratus) sebagai Larvasida Larva Aedes sp dengan konsentrasi 2,5\%, 2\%, 1,5\%,1\%, $0,5 \%, 0,25 \%, 0,1 \%$ dan $0,05 \%$ serta kelompok kontrol positif abate $1 \%$ dan kontrol negatif $0 \%$. Dari hasil penelitan diperoleh bahwa efektivitas ekstra daun serai sebagai larvasida nyamuk larva Aedes sp memiliki konsentrasi sebagai larvasida nyamuk Aedes $s p$ dalam waktu pengamatan selama 12 jam.

Berdasarkaan Pra-Lab yang telah dilakukan sebelumnya dengan mengggunakan perasan daun serai terhadap kematian Aedes aegypti dengan konsetrasi $0 \%, 15 \%, 30 \%$ dan $45 \%$, dan waktu pengamatan selama 6 jam, 12 jam, 18 jam dan 24 jam, hasil yang didapatkan yaitu pada kosentrasi $15 \%$ terdapat 3 ekor larva yang mati, pada konsentrasi $30 \%$ sebanyak 3 ekor larva yang mati dan pada konsentrasi $45 \%$ sebanyak 6 ekor larva yang mati. Jadi dapat dikatakan bahwa pada konsentrasi yang paling optimal untuk perasan daun serai yaitu pada konsentrasi $45 \%$ yang menyebabkan kematian pada larva Aedes aegypti yang 
berjumlah 6 ekor larva dalam waktu 24 jam setelah perlakuan.

Berdasarkan latar belakang diatas, maka peneliti tertarik melakukan penelitian mengenai "Pengaruh Perasan Daun Serai Dapur (Cymbopogon citratus) Terhadap Kematian Larva Aedes aegypti”.

\section{METODE PENELITIAN}

Tempat penelitian dilakukan di dua tempat yaitu di Kelurahan Hunggaluwa Kecamatan Limboto Kabupaten Gorontalo (tempat perkembang biakan nyamuk) dan pembuatan daun serai (Cymbopogon citratus) di lakukan di Laboratorium kesehatan masyarakat UNG. Penelitian dilakukan pada akhir Bulan Oktober tahun 2019. Penelitian ini merupakan penelitian eksperimental dengan menggunakan desain penelitian True Experimental karena sampel larva Aedes aegypti mendapat perlakuan langsung dengan dimasukkan kedalam perasan daun serai (Cymbopogon citratus) dengan menggunakan konsentrasi 15\%, 30\%, dan $45 \%$. Pada penelitian ini akan dilakukan 4 perlakuan pada masing-masing konsentrasi dan dilakukan tiga (3) kali pengulangan yang diamati selama waktu 6 jam, 12 jam, 18 jam, dan 24 jam untuk melihat pengaruh daun serai dalam membunuh larva nyamuk Aedes aegypti. Variabel bebas atau independent variabel dalam penelitian ini yaitu perasan daun serai (Cymbopogon citratus) dan waktu pengamatan. Variabel terikat atau dependent variabel dalam penelitian ini adalah kematian larva Aedes aegypti yang di hitung berdasarkan jumlah larva yang mati dalam kurun waktu tertentu yang di lihat sesuai konsentrasi.

Populasi dalam penelitian ini yaitu larva Aedes aegypti yang di kembang biakkan di kelurahan Hunggaluwa Kecamatan Limboto Kabupaten Gorontalo. Sampel dalam penelitian ini yaitu larva Aedes aegypti Instar II dengan jumlah 540 ekor larva. Setiap konsentrasi dimasukkan 15 ekor larva.

Analisis data pada penelitian ini yaitu :
1) Uji Normalitas Data, Uji normalitas data dilakukan karena untuk mengetahui apakah data tersebut berdistribusi normal atau tidak, uji normalitas yang akan dilakukan dalam penelitian ini adalah Uji Kolmogorov-Smirnov.

2) Uji Homogenitas Data, Uji homogenitas dilakukan untuk mengetahui apakah data tersebut homogeny atau tidak, suatu data dikatakan homogeny apabilla pada Homogeneity test (test homogenisasi) yaitu Levene's Test of Equality Error Variances, diperoleh nilai $\mathrm{p}$-value $>\alpha$ $=0,05$.

3) Uji Analisis Varians Dua Arah ( TwoWay ANOVA ), Analisis Varians Dua Arah (Two-Way Analysis of Variance) dalam analisis ini terdapat dua faktor yang mungkin menyebabkan perbedaan dalam variabel terikat (dependent variable).

\section{HASIL DAN PEMBAHASAN}

\subsection{Hasil}

Penelitian ini menggunakan perasan daun serai dapur sebagai larvasida nabati untuk membunuh larva nyamuk Aedes aegypti dengan berbagai macam konsentrasi. Dalam penelitian ini pengaruh perasan daun serai dapur (Cymbopogon citratus) di amati selama 6 jam, 12 jam, 18 jam dan 24 jam. Daun serai dapur yang di gunakan dalam penelitian ini sebanyak $2 \mathrm{~kg}$ yang menghasilkan $1.080 \mathrm{ml}$ perasan murni yang dilakukan dalam 3 kali pengulangan. Larva nyamuk Aedes aegypti yang digunakan dalam penelitian ini sebanyak 540 ekor larva. Larva di peroleh dari kelurahan Hunggaluwa Kecamatan Limboto Kabupaten Gorontalo. Larva yang digunakan adalah larva instar II. Adapun hasil penelitian dapat di lihat pada tabel berikut. 
Tabel 4.1 Jumlah Kematian Larva Nyamuk Aedes Aegypti Dengan Berbagai Konsentrasi Perasan Daun Serai Dapur (Cymbopogon Citratus) Setelah 6 Jam, 12 Jam, 18 Jam Dan 24 Jam Perlakuan

\begin{tabular}{|c|c|c|c|c|c|c|c|c|c|c|}
\hline \multirow{3}{*}{$\begin{array}{c}\text { Konsentrasi } \\
\text { Daun } \\
(\%)\end{array}$} & \multirow{3}{*}{$\begin{array}{c}\text { Jumlah } \\
\text { Larva }\end{array}$} & \multirow{3}{*}{$\begin{array}{c}\text { Waktu } \\
\text { Pengamatan } \\
\text { (Jam) }\end{array}$} & \multicolumn{6}{|c|}{ Kematian Larva Pada Pengulangan Ke- } & \multirow{2}{*}{\multicolumn{2}{|c|}{ Rata-Rata }} \\
\hline & & & \multicolumn{2}{|c|}{ I } & \multicolumn{2}{|c|}{ II } & \multicolumn{2}{|c|}{ III } & & \\
\hline & & & $\mathbf{n}$ & $\%$ & $\mathbf{n}$ & $\%$ & $\mathbf{n}$ & $\%$ & $\mathbf{n}$ & $\%$ \\
\hline \multirow{4}{*}{$\mathrm{s} 0 \%$} & 15 & $6 \mathrm{Jam}$ & 0 & 0 & 0 & 0 & 0 & 0 & 0 & 0 \\
\hline & 15 & $12 \mathrm{Jam}$ & 0 & 0 & 0 & 0 & 0 & 0 & 0 & 0 \\
\hline & 15 & $18 \mathrm{Jam}$ & 0 & 0 & 0 & 0 & 0 & 0 & 0 & 0 \\
\hline & 15 & 24 Jam & 0 & 0 & 0 & 0 & 0 & 0 & 0 & 0 \\
\hline \multirow{4}{*}{$15 \%$} & 15 & 6 Jam & 3 & 20.0 & 3 & 20.0 & 4 & 27.0 & 3 & 22 \\
\hline & 15 & $12 \mathrm{Jam}$ & 4 & 27.0 & 6 & 40.0 & 5 & 33.0 & 5 & 33 \\
\hline & 15 & $18 \mathrm{Jam}$ & 7 & 47.0 & 9 & 60.0 & 8 & 53.0 & 8 & 53 \\
\hline & 15 & $24 \mathrm{Jam}$ & 9 & 60.0 & 10 & 67.0 & 11 & 73.0 & 10 & 67 \\
\hline \multirow{4}{*}{$30 \%$} & 15 & $6 \mathrm{Jam}$ & 6 & 40.0 & 6 & 40.0 & 7 & 47.0 & 6 & 42 \\
\hline & 15 & $12 \mathrm{Jam}$ & 8 & 53.0 & 7 & 47.0 & 9 & 60.0 & 8 & 53 \\
\hline & 15 & $18 \mathrm{Jam}$ & 10 & 67.0 & 11 & 73.0 & 11 & 73.0 & 11 & 71 \\
\hline & 15 & 24 Jam & 12 & 80.0 & 12 & 80.0 & 13 & 87.0 & 12 & 82 \\
\hline \multirow{4}{*}{$45 \%$} & 15 & $6 \mathrm{Jam}$ & 7 & 47.0 & 7 & 47.0 & 8 & 53.0 & 7 & 49 \\
\hline & 15 & $12 \mathrm{Jam}$ & 10 & 67.0 & 10 & 67.0 & 11 & 73.0 & 10 & 69 \\
\hline & 15 & $18 \mathrm{Jam}$ & 13 & 87.0 & 12 & 80.0 & 14 & 93.0 & 13 & 87 \\
\hline & 15 & 24 Jam & 15 & 100 & 15 & 100 & 15 & 100 & 15 & 100 \\
\hline
\end{tabular}

Sumber : Data Primer 2019

Dari tabel 4.1 dapat di lihat bahwa, setelah di lakukan 3 kali pengulangan dapat diketahui bahwa pada kelompok perlakuan menunjukan rata-rata jumlah kematian larva yang paling tinggi terdapat pada konsentrasi $45 \%$ selama 24 jam yaitu sebanyak 15 ekor larva yang mati dengan persentase sebesar $100 \%$, sedangkan jumlah rata-rata kematian larva terendah terdapat pada konsentrasi $15 \%$ dalam waktu pengamatan selama 6 jam yaitu sebanyak 3 ekor larva yang mati dengan persentase sebesar $22 \%$ dan pada kelompok kontrol dengan persentase $0 \%$ tidak ditemukan adanya larva yang mati pada semua pengulangan, hal ini di sebabkan pada kelompok kontrol, larva hanya diberi aquades tanpa campuran perasan daun serai dapur. Pada hasil yang didapatkan tidak terdapat larva yang mati sehingga aquades dianggap tidak memiliki sifat larvasida terhadap Aedes aegypti.

Berdasarkan hasil uji pada tabel 4.1 jumlah kematian larva pada setiap perlakuan dalam waktu 6 jam, 12 jam, 18 jam dan 24 jam pada 3 kali pengulangan dapat dibuat diagram untuk menggambarkan respon ratarata kematian larva nyamuk Aedes aegypti terhadap konsentrasi perasan daun serai dapur (Cymbopogon citratus).

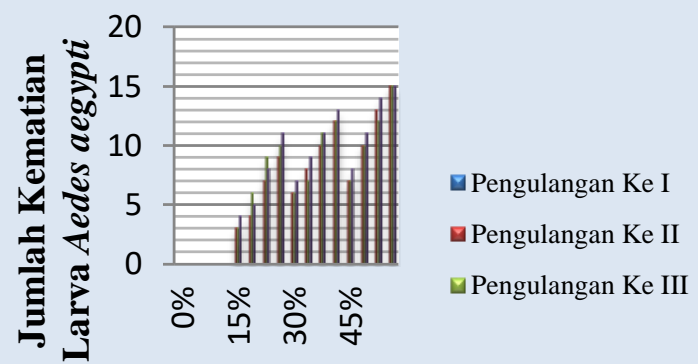

\section{Konsentrasi Perasan Daun Serai} Dapur

Gambar 4.1 Jumlah Kematian Larva

Nyamuk Aedes aegypty

Analisis data yang didapatkan pada hasil penelitian yaitu

1) Uji Normalitas Data, Uji normalitas data dilakukan karena untuk msengetahui apakah data tersebut berdistribusi normal atau tidak, uji normalitas data yang akan dilakukan dalam penelitian ini adalah Uji Kolmogorov-Smirnov. Berdasarkan uji normalitas data dapat dilihat bahwa data berdistribusi normal dimana untuk kematian larva Aedes aegypti asymp. Sig. $(2$-tailed $)=0.139$ (lampiran 1) dan $\alpha=0.05$, maka p-value 0.139>0.05. Dengan melihat hasil uji normalitas data tersebut, dapat disimpulkan bahwa data berdistribusi normal.

2) Uji Homogenitas Data, Uji homogenitas data dilakukan untuk mengetahui apakah data tersebut homogen atau tidak, suatu data dikatakan homogen apabila data Homogeneity Test (test homogenisasi) yaitu Levene's Test of Equality Error Variances, diperoleh nilai signifikannya $0.054>0,05$ (lampiran 1) jadi dapat disimpulkan bahwa data tersebut adalah homogen. 
3) Uji Two-Way-ANOVA, Berdasarkan uji yang telah dilakukan data berdistribusi normal dan memiliki varian data yang sama atau homogen, sehingga memenuhi persyaratan untuk dilakukan uji statistik TwoWay-ANOVA. Hasil uji Two-WayANOVA menunjukan nilai signifikannya $0,000 \quad(\mathrm{p}<0,05)$ (lampiran 1), sehingga dapat diartikan bahwa ada perbedaan yang signifikan antara kelompok perlakuan yaitu antara kelompok kontrol, kelompok perlakuan perasan daun serai dapur $15 \%, \quad 30 \%$ dan $45 \%$ terhadap kematian larva nyamuk Aedes aegypti. Maka dapat disimpulkan bahwa masing-masing konsentrasi perlakuan perasan daun serai dapur terdapat perbedaan yang efektif terhadap kematian larva nyamuk Aedes aegypti.

4) Uji Post Hoc (Tukey HSD), Uji HSD (Tukey's Honestly Significance Difference Test) atau sering disebut uji BNJ (Beda Nyata Jujur) merupakan uji yang dilakukan jika terdapat perbedaan efektif. Uji Post Hoc dilakukan untuk mengetahui perbedaan antara perlakuan. Hasilnya menunjukan ( $\mathrm{p}$ mendekati 0,05) (lampiran 1) pada setiap perlakuan, sehingga dari pengujian ini dapat diartikan bahwa terdapat perbedaan kematian larva nyamuk Aedes aegypti yang signifikan antara konsentrasi kelompok perlakuan dan kelompok kontrol.

\subsection{Pembahasan}

3.2.1 Pengaruh Perasan Daun Serai Dapur (Cymbopogon Citratus) Terhadap Kematian Larva Aedes Aegypti

Berdasarkan tabel 4.1 dan gambar 4.1 menunjukan bahwa perasan daun serai dapur (Cymbopogon citratus) dapat menyebabkan kematian larva Aedes aegypti instar II mulai dari konsentrasi $15 \%, 30 \%$ dan $45 \%$ selama 6 jam, 12 jam, 18 jam dan 24 jam dengan 3 kali pengulangan. Di peroleh jumlah kematian larva Aedes aegypti pada konsentrasi dan waktu yang berbeda. Lamanya perlakuan juga menentukan nilai persentase kematian larva Aedes aegypti instar II.

Pengaruh perasan daun serai dapur (Cymbopogon Citratus) terhadap kematian larva Aedes aegypti di sebabkan oleh adanya senyawa aktif yang yang terkandung dalam insektisida alami akan terakumulasi di dalam tubuh serangga akan berperan sebagai toksikan. Toksikan tersebut akan berdistribusi keseluruh sel-sel tubuh melalui peredaran darah serangga yang mengakibatkan seluruh sirkulasi dalam tubuh akan terganggu. Apabila sekresi enzim terganggu maka proses pencernaan makanan juga akan terganggu sehingga larva akan kekurangan energi dan lama-kelamaan akan mengalami kematian (Yudi,2004).

Tingginya angka kematian larva dapat di sebabkan oleh adanya kandungan senyawa kimia pada daun serai dapur. Pada penelitian ini di dapatkan bahwa perasan daun serai dapur mempunyai pengaruh terhadap kematian larva Aedes aegypti. Menurut Sastriawan (2014), bahan aktif yang terkandung dalam daun serai dapur diantaranya yaitu Sitronelal, Sitronelol, Geraniol, Minyak Atsiri. Oleh karena itu apabila senyawa-senyawa ini masuk kedalam tubuh larva, maka alat pencernaan larva akan terganggu. Selain itu akan menghambat reseptor perasa pada daerah mulut larva. Hal ini dapat mengakibatkan larva gagal mendapatkan stimulasi rasa sehingga larva tidak mampu mengenali makannya, akibatnya larva mengalami kematian.

Menurut Kardinan (2003) bahwa Sitronelal ini memiliki sifat racun kontak. Sebagai racun kontak, Sitronelal dan geraniol merupakan bahan aktif yang tidak disukai dan sangat dihindari oleh serangga, termasuk 
nyamuk sehingga penggunaan bahan-bahan ini sangat bermanfaat sebagai bahan obat pengusir atau penolak nyamuk yang dapat menyebabkan kematian akibat kehilangan cairan secara terus-menerus sehingga tubuh nyamuk akan kekurangan cairan. Selain itu kandungan kimia lainnya yaitu minyak atsiri kandungan ini mempunyai aktivitas sebagai anti nyamuk. Menurut Apriyani (2016), Abu dari daun dan tangkainya mengandung $49 \%$ silica yang merupakan penyebab desikasi (keluarnya cairan tubuh secara terusmenerus) pada kulit serangga sehingga menyebabkan serangga akan mati kering.

Selain diakibatkan oleh adanya kandungan kimia dari daun serai, kematian larva Aedes aegypti juga disebabkan oleh adanya pengaruh tingkat konsentrasi. Pada kelompok konsentrasi uji di masing-masing konsentrasi yang telah di beri perlakuan di dapatkan hasil yang berbeda hal ini karena semakin rendah konsentrasi perasan maka tingkat kematian larva juga akan rendah, begitupun sebaliknya jika konsentrasi perasan tinggi maka tingkat kematian larva juga akan semakin tinggi. Pada penelitian sebelumnya yang dilakukan oleh Sastriawan (2014) dengan judul Efektivitas Serai Dapur (Cymbopogon citratus) Sebagai Larvasida Pada Larva Nyamuk Aedes Sp Instar III/IV diman pada umumnya semakin tinggi konsentrasi suatu larutan mengakibatkan banyak angka kematian larva Aedes aegypti.

Maka dapat di simpulakan bahwa perasan daun serai dapur (Cymbopogon citratus) memiliki efek larvasida terhadap kematian larva Aedes aegypti, hal ini di karenakan dengan semakin meningkatnya konsentrasi yang digunakan maka senyawa toksit yang bersifat racun yang masuk ke dalam tubuh larva akan terakumulasi semakin banyak sehingga mengakibatkan aktivitas hidup larva terganggu dan pada akhirnya menyebabkan kematian.

Dari hasil penelitian yang telah dilakukan dapat diketahui bahwa perasan daun serai dapur (Cymbopogon citratus) memiliki pengaruh terhadap kematian larva Aedes aegypti karena dapat membunuh larva Aedes aegypti hingga mencapai $100 \%$ dalam tingkat konsentrasi $45 \%$.

3.2.2 Analisis konsentrasi yang paling efektif dari perasan daun serai dapur (cymbopogon citratus) terhadap kemetian larva aedes aegypti

Berdasarkan hasil penelitian pada tabel 4.1 dan gambar 4.1 menunjukan rata-rata jumlah kematian larva Aedes aegypti setelah di biarkan dalam larutan perasan daun serai dapur. Pada kelompok kontrol menggunakan aquades $100 \mathrm{ml}$ untuk mengetahui adanya kemungkinan efek larvasida dari aquades yang digunakan dalam penelitian ini. Secara statistik pada kelompok kontrol di dapatkan jumlah kematian larva sebesar 0\% pada semua pengulangan hal ini berarti tidak terdapat larva yang mati karena disebabkan pada kelompok kontrol ini merupakan kelompok yang tidak diberi perlakuan apapun dalam hal ini aquades yang berguna sebagai media larva Aedes aegypti tidak diberi campuran larvasida sehingga dapat disimpulakan bahwa pada kelompok kontrol tidak terdapat efek larvasida dari aquades yang digunakan. Sedangkan pada kelompok perlakuan ditemukan ada larva yang mati. Hal ini dapat dilihat dari perbandingan jumlah larva yang mati dari tiap-tiap konsentrasi. Dimana konsentrasi perasan daun serai dapur memberikan pengaruh yang berbeda-beda pada kematian larva Aedes aegypti

Perasan dapat menyebabkan kematian larva Aedes aegypti instar II karena larva instar II ini lebih mudah mati hal ini diakibatkan karena larva instar II kekebalan tubuhnya masih lemah dibandingkan dengan larva instar III. Sanjaya (2006) mengatakan bahwa semakin dewasa larva maka daya tahan tubuhnya semakin tinggi hal ini disebabkan oleh lapisan kulit larva instar III lebih tebal dari pada larva instar II hal ini 
sejalan dengan Kaihena, dkk (2012) yang mengemukakan bahwa kematian larva berhubungan dengan adanya ketahanan dari masing-masing jenis larva nyamuk terhadap ekstrak dan adanya perbedaan ukuran larva ini menyebabkan larva dengan ukuran yang lebih besar akan lebih tahan terhadap berbagai insektisida.

Kematian larva di mulai dari konsentrasi terendah yaitu konsentrasi $15 \%$ sampai dengan konsentrasi tertinggi yaitu konsentrasi $45 \%$. Dalam penelitian ini konsentrasi yang paling banyak terhadap kematian larva Aedes aegypti yaitu pada konsentrasi $45 \%$ dengan rata-rata jumlah kematian larva sebesar 15 ekor larva dengan persentase $100 \%$ dan yang paling sedikit terdapat pada konsentrasi $15 \%$ dengan ratarata jumlah kematian larva sebesar 3 ekor larva dengan persentase $22 \%$. Kematian larva ini disebabkan karena semakin tinggi konsentrasi maka jumlah kematian larva semakin tinggi pula. Hal ini disebabkan karena daun serai dapur mengandung senyawa kimia atau senyawa aktif yang dapat membunuh larva Aedes aegypti. Pada penelitian sebelumnya yang dilakukan oleh Raditya (2018) dengan judul Uji Efektivitas Ekstra Daun Serai (Cymbopogon citratus) sebagai Larvasida Larva Aedes sp, bahwa semakin tinggi konsentrasi ekstra ethanol daun serai dapur maka akan semakin besar efektivitasnya dalam membunuh larva Aedes $s p$.

Pada kelompok waktu pengamatan kematian larva nyamuk Aedes aegypti paling tinggi yaitu pada waktu pengamatan selama 24 jam dan yang paling rendah pada waktu pengamatan selama 6 jam. Semakin lama pajanan waktu terhadap larva maka semakin tinggi pula jumlah kematian larva. Menurut Handayani (2013), bahwa seiring dengan bertambahnya waktu, persentase kematian larva nyamuk pada setiap perlakuan yang diberikan menunjukan adanya peningkatan yang bervariasi, sesuai dengan besarnya dosis yang diberikan, semakin menunjukan potensi yang cukup tinggi setiap waktu pengamatan.

Dalam penelitian ini dapat dilihat bahwa pada setiap pengulangan hasilnya selalu berganti-ganti, sementara sampelnya berasal dari larva yang sama dan perasan yang sama. Hal ini dikarenakan adanya perbedaan daya sensitifitas masing-masing larva terhadap konsentrasi perasan daun serai dapur, dimana semakin tinggi konsentrasinya maka semakin tinggi tingkat kekentalan larutan sehingga larva lebih cepat mati di bandingkan dengan larva yang hanya mendapat perlakuan dengan konsentrasi yang lebih rendah. Serta semakin banyak pula senyawa-senyawa kimia yang bersifat racun yang diterima atau terkontak langsung dengan larva pada media penelitian. Selain konsentrasi faktor suhu juga mempengaruhi kematian larva Aedes aegypti. Namun suhu dari konsentrasi perasan daun serai dapur sebelum dan sesudah perlakuan tidak sempat dilakukan pengukuran suhu. menurut Pratiwi, dkk (2013), bahwa kondisi yang optimal bagi pertumbuhan dan perkembangan larva Aedes aegypti yaitu pada suhu $24-28^{\circ} \mathrm{C}$.

Pada penelitian sebelumnya oleh Raditya (2018) meneliti tentang Uji Efektivitas Ekstra Daun Serai (Cymbopogon citratus) sebagai Larvasida Larva Aedes sp dimana dalam penelitiannya menunjukan konsentrasi ekstra paling banyak membunuh larva Aedes sp yaitu pada konsentrasi 2,5\% dan $2 \%$ dengan persentase kematian sebesar $100 \%$. Perbedaan hasil penelitian ini terletak pada tingkat konsentrasi, jumlah larva yang digunakan pada tiap-tiap konsentrasi serta waktu pengamatan. Jika penelitian sebelumnya menggunakan larva instar III dalam waktu 12 jam dengan 3 kali pengulangan serta larva yang digunakan pada tiap-tiap konsentrasi sebanyak 25 ekor larva. Sedangkan penelitian ini menggunakan perasan daun serai dapur dengan konsentrasi 
$15 \%, \quad 30 \%$ dan $45 \%$ dengan 3 kali pengulangan dan diamati selama 6 jam,12 jam,18 jam dan 24 jam serta jumlah larva yang digunakan pada tiap-tiap konsentrasi sebanyak 15 ekor larva nyamuk Aedes aegypti.

Untuk membuktikan hipotesis bahwa terdapat perbedaan jumlah kematian larva Aedes aegypti terhadap masing-masing konsentrasi maka dilakukan uji Two Way ANOVA dari hasil uji Two Way ANOVA menunjukan bahwa nilai probabilitas sebesar 0.000 . Karena nilai probabilitas $<\alpha 0,05$ maka H1 diterima, hal ini berarti terdapat perbedaan daya bunuh perasan daun serai dapur dengan konsentrasi 15\%, 30\% dan 45\% dalam membunuh larva nyamuk Aedes aegypti.Dengan demikian dapat disimpulkan bahwa adanya pengaruh konsentrasi perasan daun serai dapur (Cymbopogon citratus) terhadap kematian larva Aedes aegypti. Setelah dilakukan uji ANOVA, dilanjutkan dengan uji lanjutan atau uji Post Hoc (Tukey $H S D)$. Dari hasil pengujian di dapat hasil yaitu nilai signifikan 0,000 ( $p$ mendekati 0,05 ) pada setiap perlakuan yang berarti terdapat perbedaan rata-rata jumlah kematian larva Aedes aegypti pada masing-masing konsentrasi.

\section{Kesimpulan}

Berdasarkan hasil penelitian mengenai Pengaruh Perasan Daun Serai Dapur (Cymbopogon citratus) Terhadap Kematian Larva Aedes aegypti maka dapat di simpulkan bahwa :

1. Pengaruh Perasan Daun Serai Dapur (Cymbopogon citratus) memiliki efek terhadap kematian larva Aedes aegypti instar II pada konsentrasi 15-45\% dengan persentase jumlah kematian larva dari 22\%-100\%.

2. Konsentrasi yang paling berpengaruh dari perasan daun serai dapur terhadap kematian larva Aedes aegypti yaitu pada konsentrasi $45 \%$ pada waktu pengamatan selama 24 jam dengan rata- rata jumlah kematian sebesar 15 ekor larva dengan persentase sebesar 100\%. Berdasarkan hasil uji Two Way ANOVA menunjukan bahwa nilai probabilitas sebesar $0,000<\alpha$ 0,05 maka H1 diterima.

\section{UCAPAN TERIMA KASIH}

Peneliti mengucapkan terima kasih kepada pembimbing dan pihak-pihak yang telah berkontribusi secara langsung maupun tidak langsung pada penelitian ini

\section{DAFTAR PUSTAKA}

1. Adhi Sucipta ningsih, Oktavia. 2014. Pendidikan Antikorupsi Bagi Siswa Sekolah Dasar di Kecamatan Gunung Pati, dalam Jurnal Universitas PGRI Semarang, Vol.4. No.2.

2. Anggraini, T, S. \& Cahyati, W, H,. 2017. Perkembangan Aedes aegypti Pada Berbagai Kondisi pH Air dan Salinitas Air. HIGEIA, 1 (3) : 1-10.

3. Apriyani, R.2016. Minyak Serai Wangi Sebagai Pengusir Nyamuk. Artikel. Kec. Bantuln : Yogyakarta.

4. Astriani, Y., Widawati, M. 2016. Potensi Tanaman Di Indonesia Sebagai Larvasida Alami Untuk Aedes Aegypti. Jurnal Litbang. 8 (2). 37-46. http://Ejournal.Litbang.Depkes.Go.Id/, Diakses Pada 14 Agustus 2018.

5. Ariesta AA, Suharyo. 2013. Uji efektifitas larutan daun pepaya (carica papaya) sebagai larvasida terhadap kematian larva nyamuk aedes aegypti di laboratorium B2P2VR. [Skripsi] Universitas Dian Nuswantoro.

6. Aulung Agus, Sri Rahayu, Anggitia (2014) Pengaruh Ekstrak Serai Wangi (Cymbopogon nardus) terhadap kematian Larva Aedes aegypti. Fakultas Kedokteran Universitas Indonesia. Jakarta. Diunduh 06-Januari-2017, dari Majalah Kedokteran UKI 2014. Vol. XXX. No.2 Juni-2014 
7. Bambang Sukana. Pemberantasan Vektor DBD di Indonesia. Media Litba ngkes Vol III no. 01/1993.(4).

8. Boekoesoe, L. 2015.Ancaman Demam Berdarah Dengue, Analisa Temuan Kasus Di Kota Gorontalo. Sulawesi Selatan- Makassar : Samudera Himalaya.

9. Cymbopogon citratus (lemon grass) [internet]. 2014. [cited 2014 April 14]. Available from : http://www.kew.org/sc ience conservation/plantsfungi/cymbop ogon-citratus-lemon-grass.

10. Departemen Kesehatan Republik Indonesia. 2010. Buletin Jendela Epidemiologi. Vol. 2 Agustus 2010. Pusat Data dan Surveilans Epidemiologi Departemen Kesehatan Republik Indonesia.

11. Dewi A. 2014. Uji Larvasida Ekstrak Etanol Serai (Andropogon nardus L) terhadap Larva Nyamuk Culex quinquefasciatus. Yogyajarta: Fakultas KedokteranUniversitas Gadjah Mada.

12. Dinas Kesehatan Provinsi Gorontalo. 2019. Data Kasus DBD Per Tahun di Provinsi Gorontalo. Dinas Provinsi Gorontalo.

13. Handayani. Dkk. 2013. Efektivitas Ekstra Daun Sirih (Piper battle L.) Sebagai Bioinsektisida Terhadap Kematian Nyamuk Aedes aegypti. Jurnal Penelitian. Universitas Hasanuddin : Makasar.

14. Hamzah, M. 2004. Bionomik Aedes Aegyti. Jurnal Kedokteran Kesehatan. 36 (4) : 96-901.

15. Hidana, R dan Novia, S. 2015. Efektivitas Ekstrak Daun Sereh (Cymbopogoon nardus) Sebagai Antioviposisi Terhadap Nyamuk Aedes aegypti. Jurnal Kesehatan Bakti Tunas Husada. 13:1.

16. Kardinan A., 2003. Tanaman Pengusir dan Pembasmi Nyamuk. Agromedia Pustaka. Jakarta.
17. Kaihena, M, dkk. 2012. Efektivitas Ekstrak Etanol Daun Sirih (Piper betle L.) Terhadap Mortalitas Larva Nyamuk Anopheles Sp dan Culex. 90 Molucca Medica, Volume 4, Nomor 1, Oktober 2012, hlm. 88-105

18. Kementrian Kesehatan RI. Rencana Strategis Kementerian Kesehatan Tahun 2015-2019. Jakarta: Kementerian Kesehatan RI; 2015.

19. Kementerian Kesehatan RI. Waspada Demam Berdarah. Jakarta: Pusat Data Kesehatan. 2015.

20. Kemenkes RI. (2016).Profil kesehatan Indonesia tahun 2015. Kementerian Kesehatan RI. Jakarta.

21. Kemenkes RI. (2016). Infodatin: situasi $D B D$ di Indonesia. Kementerian Kesehatan RI. Jakarta.

22. Kumar R, Krishan P, Swami G, Kaur P, Shah G, Kaur A. Pharmacognostical Investigation of Cymbopogon citratus (DC) Stapf. Scholar Research Library. 2010:181-189.

23. Luiz C , Ulisses A, Ana P,Célia R, Róbson R, Evandro d. Evaluation of the Chemical Composition of Brazilian Commercial Cymbopogon citratus (D.C.) Stapf Samples. Molecules. 2008 August:1864-1874.

24. Mulyani, S. 2014. Granul Minyak Serai Dapur Sebagai Larvasida Nyamuk Aedes aegypti. J Trad. Med. 19 (13): 139-140.

25. Muhlisah, Fauziah., 2012. Tanaman Obat Keluarga (TOGA). Depok : Penebar Swadaya.

26. Nugroho, E., Rubandiyah, H, I. (2018). Higeia Journal Of Public Health Research And Development. Semarang : Universitas Negeri Semarang.

27. Paingankar MS, et al. (2014) Monitoring of dengue and chikungunya viruses in field-caught Aedes aegypti (Diptera: Culicidae) in Surat city, India. Current Science 106(11): 1559- 1567. 
28. Pratiwi, C. Y., dkk. 2013. Efektivitas Ekstra Daun Ceremai (Phyllanthus acidus)Terhadap Mortalitas Larva Aedes aegypti. Jurnal Lentera Bio ISSN: 2252-3979 http:// ejournal. Unesa.ac.id/index.php/lenterabio. Universitas Negeri Surabaya : Surabaya.

29. Rahayu et al. 2017.Jurnal Ilmu Kesehatan Masyarakat, 8(3):200-207.

30. Sastriawan, A., 2014. Efektivitas Serai Dapur (Cymbopogon Citratus) Sebagai Larvasida Pada Larva Nyamuk Aedes Sp Instar Iii/Iv, Jakarta: Universitas Islam Negeri.

31. Soegijanto Soegeng. 2006. Demam Berdarah Dengue. Edisi kedua. Surabaya : Airlangga University Press.

32. WHO. Global strategy for dengue prevention and control 2012-2020. Switzerland: World Health Organization;2012.

33. Yulindar. 2015. Siklus Hidup Aedes aegypti pada Skala Laboratorium. Vol. 2. No.1.Aceh Besar. 